\title{
Genetics of colonizing and established populations of Primula veris
}

\author{
SUSAN ANTROBUS* \& ANDREW J. LACK \\ School of Biological and Molecular Sciences, Oxford Brookes University, Headington, Oxford OX3 OBP, U.K.
}

\begin{abstract}
Primula veris, a long-lived iteroparous herb which has declined in abundance in southern England since the $1940 \mathrm{~s}$, has recently been observed colonizing disturbed sites. The genetic structure of $P$. veris populations in the Oxford region was investigated to determine whether colonizing populations differ from those longer established. Nine enzyme systems, revealing 19 presumptive loci, were screened in 11 established and seven colonizing populations. Levels of variation were low in all populations, and all populations except one approximated panmixia. The proportion of the total variation among populations was small $\left(F_{\mathrm{ST}}=0.039\right)$ as were genetic distances between populations. No significant differences in genetic structure were recorded between established and colonizing populations. The lack of differentiation within and between populations is surprising for a long-lived, insect pollinated species with gravity dispersed seeds, for which gene flow would be expected to be spatially restricted.
\end{abstract}

Keywords: colonization, dispersal, gene flow, genetic structure, isozyme, Primula veris.

\section{Introduction}

The ability of plant species to colonize new areas and the ecological and genetic consequences of this colonization have received much study. Successful colonizing plants are likely to have a good seed dispersal mechanism and rapid reproduction or vegetative growth. Selffertility may also be an advantage. Some of the variation in a species may be lost in colonizing populations, through founder effects, and such effects have been detected at all scales of colonization from long distance to local, and among plants which are mainly inbreeding as well as those that are mainly outbreeding (Brown \& Marshall, 1981; Barrett \& Husband, 1990). Generally, inbreeding plants show more differentiation between populations and less within them than outbreeders (Loveless \& Hamrick, 1984; Hamrick \& Godt, 1990) and many show founder effects strongly, even at a local scale (Lack \& Kay, 1988).

One species that we observed colonizing new sites in Britain was the cowslip, Primula veris. This species does not appear to have the attributes of a good colonizer. It is a long-lived iteroparous perennial (Tamm, 1972) which is insect pollinated, mainly by bees, heterostylous and an obligate outcrosser (Proctor \&

*Present address: British Antarctic Survey, High Cross, Madingley Road, Cambridge, CB5 0ET, U.K.
Yeo, 1973; Wedderburn \& Richards, 1990). Pollen dispersal is normally up to $12 \mathrm{~m}$ and seed dispersal, by gravity, is normally limited to $0.5 \mathrm{~m}$ (Richards \& Ibrahim, 1978). In mature habitats, Tamm (1972) observed that recruitment of seedlings into the adult population was a rare event and that regeneration was achieved mainly by infrequent and local branching of the rhizome.

The existence of colonizing populations of this species in many places was, therefore, surprising. The aim of this study was to see what attributes it possessed which allowed it to colonize well, and what the genetic consequences of this colonization might be. We are concerned with colonization at a local scale, within the species' established range.

\section{Materials and methods}

Until the 1940s $P$. veris was an abundant meadow and pasture plant in lowland England, with extensive populations, which were likely to have been long lived due to constant cutting or grazing. Since then $P$. veris has greatly decreased in England through the destruction of many grasslands for arable use or, in those that remain, relaxation of grazing pressure leading to a less suitable habitat. Grime et al. (1988) regarded it as a stress tolerator (with some competitive ability) although they too noted that populations, some of them 
extensive, have become established on verges of motorways and in disturbed habitats.

\section{Population sampling procedure}

Populations were sampled from 18 sites (Table 1, Fig. 1 ; further details, including grid references and habitat are given by Antrobus, 1992). They ranged in size from less than a hundred individuals to many thousands. All sites were defined by a natural boundary and were less than $1 \mathrm{~km}$ in diameter; most were less than 100 m diameter. Three sites, Lower Seeds, The Dell and Upper Seeds were less than $100 \mathrm{~m}$ apart but were separated by areas with no $P$. veris plants.

Populations were classified as 'established' (populations 1-11), or 'colonizing' (populations 12-18). The established populations were growing on documented

Table 1 Location and size of $P$. veris populations; \% polymorphic loci $(P)$; mean number of alleles per locus $(A)$; observed heterozygosity $\left(H_{\circ}\right)$; and Nei's mean diversity index $(\hat{H})$

\begin{tabular}{|c|c|c|c|c|c|}
\hline Population & $\begin{array}{l}\text { Approx. } \\
\text { numbers }\end{array}$ & $P$ & $A$ & $H_{o}$ & $\hat{H}$ \\
\hline \multicolumn{6}{|l|}{ Established: } \\
\hline $\begin{array}{l}\text { 1. Blenheim } \\
\text { Palace }\end{array}$ & 700 & 10 & 1.16 & 0.021 & 0.021 \\
\hline $\begin{array}{l}\text { 2. Chilswell } \\
\text { Valley }\end{array}$ & 400 & 10 & 1.11 & 0.011 & 0.013 \\
\hline $\begin{array}{l}\text { 3. Aston } \\
\text { Rowant }\end{array}$ & $1000 \mathrm{~s}$ & 21 & 1.26 & 0.023 & 0.024 \\
\hline 4. Pulpit Hill & $1000 \mathrm{~s}$ & 10 & 1.11 & 0.008 & 0.008 \\
\hline $\begin{array}{l}\text { 5. Minster } \\
\text { Wood }\end{array}$ & 200 & 10 & 1.11 & 0.020 & 0.020 \\
\hline $\begin{array}{l}\text { 6. Stonesfield } \\
\text { Common }\end{array}$ & 1500 & 15 & 1.26 & 0.015 & 0.017 \\
\hline 7. West Mead & $1000 \mathrm{~s}$ & 15 & 1.26 & 0.022 & 0.022 \\
\hline 8. Lower Seeds & 150 & 15 & 1.21 & 0.022 & 0.021 \\
\hline 9. The Dell & 75 & 10 & 1.16 & 0.025 & 0.024 \\
\hline $\begin{array}{l}\text { 10. Hill End } \\
\text { (Triangle) }\end{array}$ & 600 & 15 & 1.26 & 0.034 & 0.031 \\
\hline $\begin{array}{l}\text { 11. Hill End } \\
\text { (Medieval) }\end{array}$ & 400 & 15 & 1.26 & 0.031 & 0.029 \\
\hline \multicolumn{6}{|l|}{ Colonizing: } \\
\hline $\begin{array}{l}\text { 12. Showells } \\
\text { Roadside }\end{array}$ & 200 & 15 & 1.16 & 0.031 & 0.031 \\
\hline 13. Quarry & 300 & 10 & 1.16 & 0.004 & 0.004 \\
\hline $\begin{array}{l}\text { 14. Lewknor } \\
\text { Roadside }\end{array}$ & 250 & 10 & 1.11 & 0.008 & 0.008 \\
\hline $\begin{array}{l}\text { 15. Cassington } \\
\text { Lagoon }\end{array}$ & 500 & 10 & 1.11 & 0.008 & 0.008 \\
\hline 16. Tar Track & 80 & 15 & 1.16 & 0.017 & 0.017 \\
\hline 17. Cumnor & $1000 \mathrm{~s}$ & 21 & 1.26 & 0.025 & 0.022 \\
\hline 18. Upper Seeds & 200 & 10 & 1.16 & 0.009 & 0.009 \\
\hline
\end{tabular}

ancient grassland sites such as West Mead or sites that were considered ancient owing to the presence of ancient grassland plant indicators, e.g. Stonesfield Common. It is likely that these populations are well established. Colonizing populations included those grówing on roadsides, in a disused quarry and a disused sewage works. The age of some of these sites is known, giving an upper age limit to the populations.

Sixty or 90 individuals were sampled from each population. To prevent sampling the same clone more than once, individuals were normally sampled $1 \mathrm{~m}$ apart. Where this was not possible, in small populations, genetic individuals were usually clear-cut and each sample came from a different genet.

\section{Electrophoresis}

Young leaves were collected from each individual between November, when the leaves first appeared above ground, and March before flower heads appeared. At other times of the year poor or no enzyme activity was detected. Leaf samples were stored at $5^{\circ} \mathrm{C}$ and were used within $48 \mathrm{~h}$ of collection. Milligram quantities of leaf tissue were homogenized with $150 \mu \mathrm{l}$ of a buffer of $0.5 \mathrm{M}$ phosphate $p \mathrm{H} 7.0$ con-

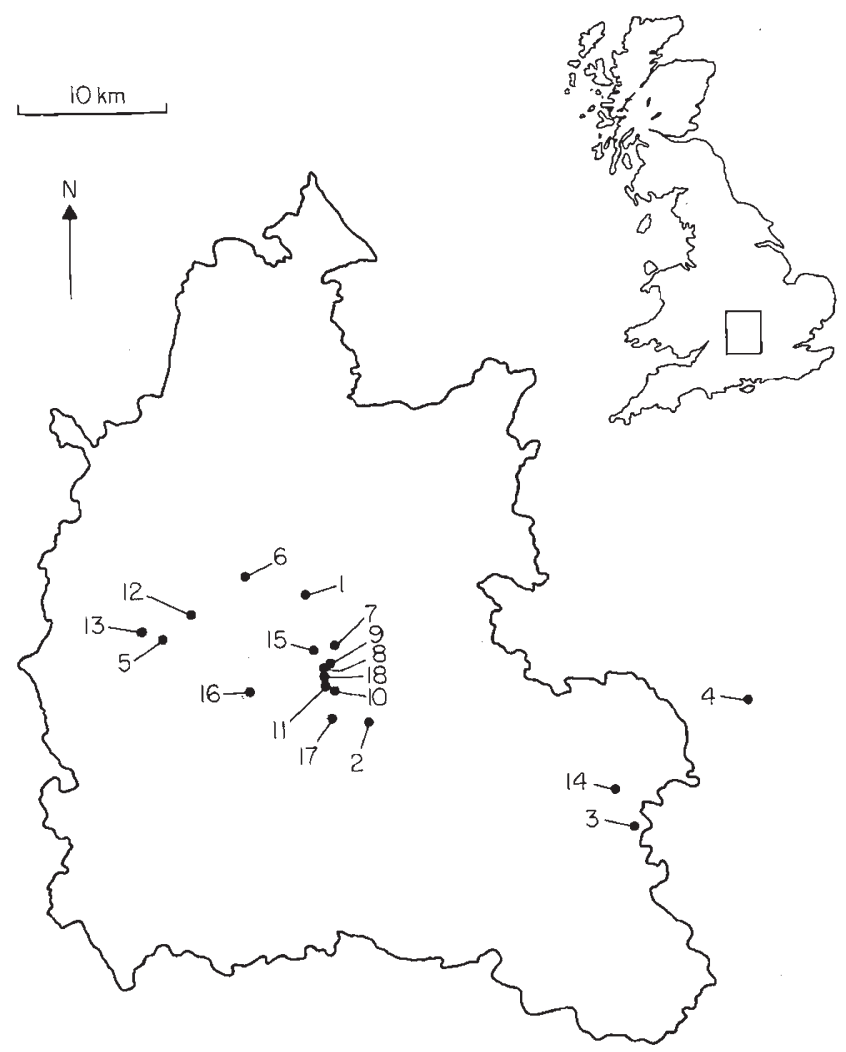

Fig. 1 Location of the populations studied, in Oxfordshire (and pop. 4 in Buckinghamshire), England. 
taining 0.5 per cent mercaptoethanol and a few grains of sand.

Extracts were absorbed onto Whatman no.3 filter paper wicks and loaded onto starch gels. Horizontal starch gel electrophoresis (10.8 per cent starch) was performed at $60 \mathrm{~mA}$ for $5 \mathrm{~h}$ (Ferguson, 1980). A discontinuous buffer consisting of $0.002 \mathrm{M}$ histidine in the gel and $0.4 \mathrm{~m}$ citrate in the electrode, both at $p \mathrm{H} 7.0$ was employed throughout. Nine enzyme systems produced bands of consistent clarity for routine screening: phosphoglucose isomerase, PGI (two loci), phosphoglucomutase, PGM (two loci), shikimate dehydrogenase SKD (two loci), malate dehydrogenase, $\mathrm{MDH}$ (one locus), alcohol dehydrogenase, $\mathrm{ADH}$ (one locus), glutamate oxaloacetate transaminase, GOT (five loci), 6-phosphogluconate dehydrogenase, 6PGD (two loci), aldolase, ALDO (two loci), isocitrate dehydrogenase, IDH (one locus) and malic enzyme, ME (two loci). Staining recipes were derived from recipes given by Shaw \& Prasad (1970).

After recording genotype frequencies, the data were analysed using the programme BIOSYs-1 (Swofford \& Selander, 1989) to calculate a range of genetic variability estimates. Wright's (1951) $F_{\text {ST }}$ statistic was used to estimate average gene flow, $\mathrm{Nm}$ (number of immigrants per generation) (Slatkin \& Barton, 1989).

\section{Heterostyly}

The proportion of long- and short-styled morphs was assessed in three established populations, 7, 9 and 10, and two colonizing populations, 17 and 18 in 1991. All flowering plants in populations 9 and 18 and 100 individuals in populations 7,10 and 17 (selected using a grid and random numbers) were scored.

\section{Results}

Nineteen loci were identified from the nine enzyme systems, four of which were polymorphic in at least one population, $A D H$, $S K D-2,6 P G D-1$ and $6 P G D-2$ (Table 2). $P G I$ and $P G M$ were polymorphic in plants from Hill End that were used for developing protocols, but were not polymorphic in any populations during sampling. Populations were polymorphic at either two, three or four loci, with an average number of alleles per locus $(\mathrm{A})$ in a population ranging from 1.11 to 1.26.

At polymorphic loci, one allele occurred at a high frequency (above 0.8), the same allele being the most frequent in all populations. No alleles were confined to a single population, but those that occurred at low frequencies were not present in all populations; e.g. at the $6 P G D-1$ locus, the fastest migrating allele (6PGD-1a) was present in only two populations. Colonizing popu-

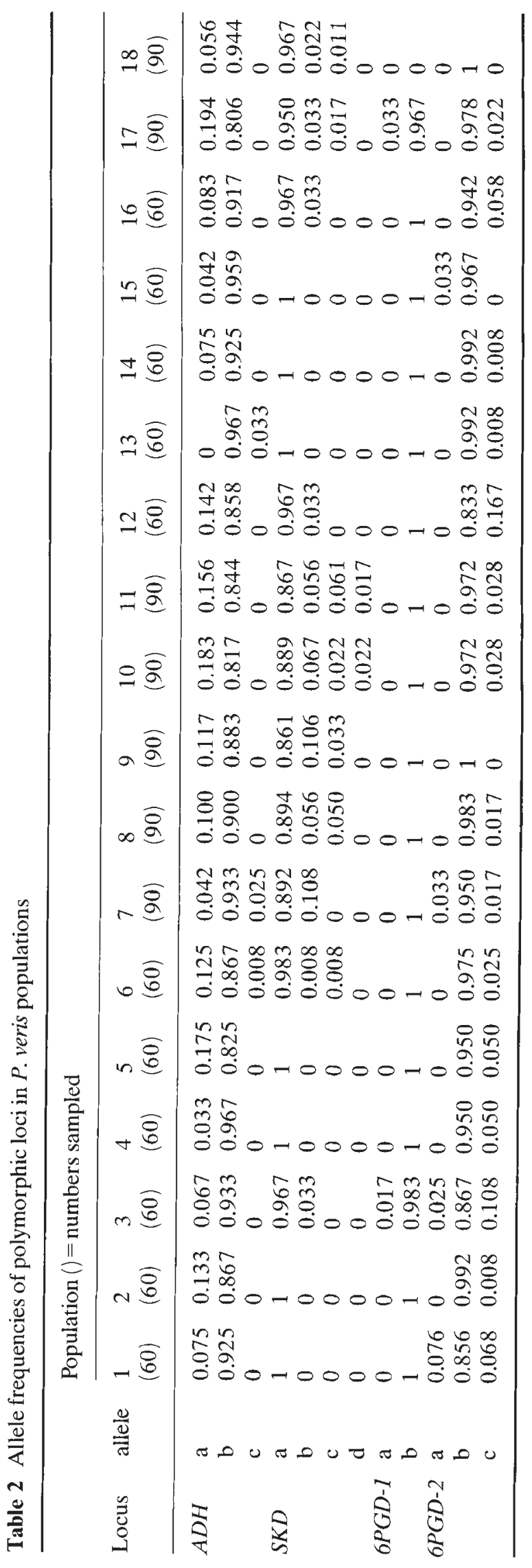


lations did not possess lower numbers of rare or uncommon alleles than established populations (Table 2) and had a similar average number of alleles per locus (Table 1).

Mean gene diversities of populations $\hat{H}$ (Nei, 1973) $\left(H_{\mathrm{CP}}\right.$ in Hamrick \& Godt, 1990) ranged from 0.004 to 0.031 (Table 1). The mean of these values in the colonizing populations $(0.014)$ was lower than that in established populations (0.021), but not significantly $(t=1.63)$. The established population at Pulpit Hill, consisting of many thousands of individuals, had a low value of 0.008 , while colonizing populations from Cumnor and Showells roadside exhibited gene diversi- ties as high as many established populations $(>0.02)$. Small established populations such as Minster Wood had similar levels of variation to large populations such as West Mead. Genotype frequencies at each polymorphic locus were not significantly different from those expected under Hardy-Weinberg equilibrium, apart from those at loci $6 P G D-1$ and $6 P G D-2$ at Cumnor (Table 3). Mean values of Wright's fixation index $(F)$ were small, less than 0.102 , except at Cumnor.

The level of genetic differentiation between populations, $F_{S T}\left(G_{\mathrm{ST}}\right.$ in Hamrick \& Godt, 1990), estimated from each of the five polymorphic loci, ranged from

Table 3 Values of Wright's fixation index $(F)$ for polymorphic loci

\begin{tabular}{|c|c|c|c|c|c|}
\hline Population & $A D H$ & $S K D$ & $6 P G D-1$ & $6 P G D-2$ & Mean \\
\hline 1 & $\begin{array}{l}-0.081 \\
\text { NS }\end{array}$ & - & - & $\begin{array}{l}+0.011 \\
\text { NS }\end{array}$ & -0.035 \\
\hline 2 & $\begin{array}{l}+0.135 \\
\text { NS }\end{array}$ & - & - & $\begin{array}{l}-0.008 \\
\text { NS }\end{array}$ & +0.064 \\
\hline 3 & $\begin{array}{l}-0.071 \\
\text { NS }\end{array}$ & $\begin{array}{l}-0.034 \\
\text { NS }\end{array}$ & $\begin{array}{l}-0.017 \\
\text { NS }\end{array}$ & $\begin{array}{l}+0.154 \\
\text { NS }\end{array}$ & +0.008 \\
\hline 4 & $\begin{array}{l}-0.034 \\
\text { NS }\end{array}$ & - & - & $\begin{array}{l}-0.053 \\
\text { NS }\end{array}$ & -0.044 \\
\hline 5 & $\begin{array}{l}-0.097 \\
\text { NS }\end{array}$ & - & - & $\begin{array}{l}+0.298 \\
\text { NS }\end{array}$ & +0.101 \\
\hline 6 & $\begin{array}{l}+0.142 \\
\text { NS }\end{array}$ & $\begin{array}{l}-0.013 \\
\mathrm{NS}\end{array}$ & - & $\begin{array}{l}-0.026 \\
\mathrm{NS}\end{array}$ & +0.034 \\
\hline 7 & $\begin{array}{l}-0.054 \\
\text { NS }\end{array}$ & $\begin{array}{l}+0.051 \\
\text { NS }\end{array}$ & - & $\begin{array}{l}-0.040 \\
\mathrm{NS}\end{array}$ & -0.014 \\
\hline 8 & $\begin{array}{l}+0.012 \\
\text { NS }\end{array}$ & $\begin{array}{l}-0.029 \\
\text { NS }\end{array}$ & - & $\begin{array}{l}-0.017 \\
\text { NS }\end{array}$ & -0.011 \\
\hline 9 & $\begin{array}{l}-0.024 \\
\text { NS }\end{array}$ & $\begin{array}{l}-0.038 \\
\text { NS }\end{array}$ & - & - & -0.031 \\
\hline 10 & $\begin{array}{l}-0.224 \\
\text { NS }\end{array}$ & $\begin{array}{l}-0.087 \\
\text { NS }\end{array}$ & - & $\begin{array}{l}+0.215 \\
\text { NS }\end{array}$ & -0.032 \\
\hline 11 & $\begin{array}{l}-0.015 \\
\text { NS }\end{array}$ & $\begin{array}{l}-0.103 \\
\text { NS }\end{array}$ & - & $\begin{array}{l}-0.029 \\
\text { NS }\end{array}$ & -0.049 \\
\hline 12 & $\begin{array}{l}-0.004 \\
\text { NS }\end{array}$ & $\begin{array}{l}-0.034 \\
\text { NS }\end{array}$ & - & $\begin{array}{l}-0.040 \\
\text { NS }\end{array}$ & -0.026 \\
\hline 13 & $\begin{array}{l}-0.034 \\
\text { NS }\end{array}$ & - & - & $\begin{array}{l}-0.008 \\
\text { NS }\end{array}$ & -0.021 \\
\hline 14 & $\begin{array}{l}-0.081 \\
\text { NS }\end{array}$ & - & - & $\begin{array}{l}-0.008 \\
\text { NS }\end{array}$ & -0.045 \\
\hline 15 & $\begin{array}{l}-0.043 \\
\text { NS }\end{array}$ & - & - & $\begin{array}{l}-0.034 \\
\text { NS }\end{array}$ & -0.039 \\
\hline 16 & $\begin{array}{l}+0.127 \\
\text { NS }\end{array}$ & $\begin{array}{l}-0.034 \\
\text { NS }\end{array}$ & - & $\begin{array}{l}-0.062 \\
\text { NS }\end{array}$ & +0.010 \\
\hline 17 & $\begin{array}{l}-0.100 \\
\text { NS }\end{array}$ & $\begin{array}{l}+0.190 \\
\text { NS }\end{array}$ & $\begin{array}{l}+0.655 \\
*\end{array}$ & $\begin{array}{l}+0.489 \\
*\end{array}$ & +0.309 \\
\hline 18 & $\begin{array}{l}-0.059 \\
\text { NS }\end{array}$ & $\begin{array}{l}-0.027 \\
\text { NS }\end{array}$ & - & - & -0.043 \\
\hline
\end{tabular}

NS $=$ not significant, $*=P<0.05$ from $\chi^{2}$ tests for departures from HardyWeinberg equilibrium. 
0.025 for $6 P G D-1$ to 0.050 for $6 P G D-2$, with a mean of 0.039 , i.e. only 3.9 per cent of the total genetic variability resided among populations. The $F_{S T}$ for colonizing populations was 0.046 compared with that of 0.033 for established populations. $\mathrm{Nm}$ values of these polymorphic loci ranged from 4.8 for $6 P G D-2$ to 9.8 for $6 P G D-1$, and any value greater than 1 indicates much gene flow between populations.

Nei's (1972) genetic distances for each pair-wise comparison of populations ranged from less than 0.001 to 0.010 (mean 0.004). Clustering using the methods of Cavalli-Sforza \& Edwards (1967), Nei (1972) and Rogers (1972) grouped the populations differently with no clear evidence of order either geographically or between established and colonizing populations except for a grouping of five populations which grew close together $(8-11,18)$.

The proportion of long- and short-styled morphs did not differ between sites $\left(\chi^{2}=2.77\right.$, d.f. $\left.=4\right)$ and did not depart from a $1: 1$ ratio $\left(\chi^{2}=0.036\right.$, d.f. $\left.=1\right)$. From casual counts and observations, all other sites appeared to have equal ratios.

\section{Discussion}

Levels of genetic variation in plant populations are highly variable (Hamrick et al., 1979; Hamrick \& Godt, 1990) and those reported here are substantially lower than the mean values reported, although within the range for outcrossing perennials. For the percentage of polymorphic loci, $P$, these $P$. veris populations were below one standard error of the mean values, and for mean gene diversity, $\hat{H}$, below two standard errors (Hamrick \& Godt, 1990). This means that $P$. veris has unusually little variation, despite its heterostylous outcrossing system and a wide distribution in Europe. The closely related Primula vulgaris, the primrose, also had little variation though not as low as $P$. veris $(P$. vulgaris mean $P=25, \hat{H}=0.074$; Cahalan, 1983).

The inbreeding coefficient values (Wright's fixation index, $F$ ) are close to zero in all populations and lower than those reported for insect pollinated outcrossing species (Brown, 1979). This indicates obligate outcrossing and almost complete panmixia, which is rarely realized in natural populations of outcrossing species due to breeding between relatives from leptokurtic dispersal of pollen and seeds (Levin \& Kerster, 1974; Brown, 1979).

Only two of the $46 \chi^{2}$ tests for Hardy-Weinberg equilibrium showed significant departures from expectations. Both departures occurred in the same site, Cumnor, and $F$ values for all polymorphic loci were greater in this site than those in the other populations. Individuals here had formed large discrete clumps, spatially separated from each other, which could lead to fewer flights by pollinating insects between clumps than within them resulting in sibmating and restricted gene flow. Other colonizing populations were clumped, but with smaller numbers of flowering individuals, so pollinators may have moved more frequently between clumps.

Primula veris is unusual in its lack of subdivision, since genetically heterogeneous neighbourhoods have been reported in other outcrossing species and are thought to be common in plant populations (Levin \& Kerster, 1974; Epperson, 1990). It has been suggested that neighbourhood size in $P$. veris and $P$. vulgaris is small (Richards \& Ibrahim, 1978; Cahalan \& Gliddon, 1985) and Cahalan (1983) did find genetic substructuring in $P$. vulgaris, in contrast to our $P$. veris populations. Seed dispersal in $P$. vulgaris, but not $P$. veris, may be influenced by ants (Richards \& Ibrahim, 1978; S. R. J. Woodell, personal communication).

The proportion of the total variation that lay among populations was exceptionally small and lower than all mean values reported by Hamrick \& Godt (1990) and many standard errors lower than the mean values for animal-outcrossed species and species with gravity dispersed seeds (Hamrick \& Godt, 1990). Although our survey included only populations within an area of about $50 \mathrm{~km}$ diameter, this is still an extraordinarily low figure and shows that there is very little differentiation between any of the populations. This is confirmed by the high estimates of gene flow $(\mathrm{Nm})$, small genetic distance values and lack of clustering of the populations.

One possible reason is that pollen dispersal may be greater than that reported for other bee-pollinated species (Levin \& Kerster, 1974). Primula veris flowers from March to May and is visited by early queen Bombus spp., Anthophora spp. and early emerging Bombyliidae (Proctor \& Yeo, 1973; Lack, 1982). Seedset does not appear to be pollinator-limited (Antrobus, 1992), and as queens at this time of year are searching for nests, they may travel greater distances than the workers later in the year. Another possibility is that the apparent high gene flow may be a reflection of historical distribution of populations. Gene flow between populations until the 1940 s was likely to be more frequent due to their close proximity, and the destruction and fragmentation of populations has occurred recently in relation to the generation span of this longlived perennial.

We expected that colonizing populations would show evidence of founder effects but, in this study, any possible reduction in gene diversity was slight and differentiation between colonizing populations was no greater than that between established populations. It is 
possible that colonizing populations have been founded by many individuals. This is likely to have happened at Upper Seeds where the potential source, Lower Seeds, is only $50 \mathrm{~m}$ away. Deer move frequently between the two areas, and seed could be carried in earth on their hooves. The seeds of $P$. veris normally lie dormant for several months (Grime et al., 1988; personal observations) allowing the possibility of frequent 'long-distance' seed dispersal (i.e. dispersal over $5 \mathrm{~m}$ or so), not recorded by Richards \& Ibrahim (1978). The formation of separated clumps of plants was characteristic of most colonizing populations and long-distance gene flow appears to be having an overwhelming impact on the genetic structure of these populations.

Perhaps the most likely source of some of these populations is plants left in field margins from earlier, much larger populations. We have noticed individuals under hedges or in small patches of relic grassland in Oxfordshire that could act as potential seed sources for new colonies. As few as five individuals may be sufficient not to constitute a genetic bottleneck and rapid increase in numbers can overcome a genetic bottleneck (Nei et al., 1975). However Sirkkomaa (1983) showed theoretically that in populations with rare alleles (like those recorded here) the genetic structure is mainly affected by the number of founders even after many generations. It suggests that a number of individuals must have been involved in the founding of these populations.

Barrett \& Husband (1990) reported a shift in breeding system in colonizing populations of tristylous Eichhornia species. We know of no shift in breeding system of $P$. veris in any part of its range, unlike Primula vulgaris which is well known to form occasional homostyle self-fertile populations (Boyd et al., 1990). Lees (1971) reported a small, but significant, excess of thrum (short-styled) plants in one $P$. veris population in Scotland which he interpreted as possibly due to heterozygote advantage but no other deviation from a 1:1 ratio has been reported and all our populations were 1:1. Grime et al. (1988) mis represented Lees (1971) as reporting an excess of pins in colonizing populations. Pin plants are slightly more self-fertile than thrums (Wedderburn \& Richards, 1990 ), so it remains a possibility.

There is a relationship between dispersal ability and levels of gene flow in flowering plants (Govindaraju, 1988) but our study emphasises Ellstrand's (1992) view that gene flow in plants can be idiosyncratic, varying even among closely related species, and that populations and individual plants may differ. There are particular problems of studying effective seed dispersal. This makes the consequences of local colonization events difficult to predict.

\section{Acknowledgements}

We are grateful to the following for permission to visit their sites: Oxford University; Oxfordshire County Council; English Nature; and the Berkshire, Buckinghamshire and Oxfordshire Naturalists' Trust. Graham Hawker, Mary Webb and Dr Alan Hall helped in locating suitable sites.

\section{References}

ANTrobus, s. 1992. Population genetics and ecology of colonising and established populations of Primula veris. Ph.D. Thesis, Oxford Polytechnic.

BARRETT, S. C. H. AND HUSBAND, B. C. 1990. The genetics of plant migration and colonization. In: Brown, A. H. D., Clegg, M. T., Kahler, A. L. and Weir, B. S. (eds) Plant Population Genetics, Breeding and Genetic Resources. Sinauer Associates Inc., Massachusetts, pp. 254-277.

BOYD, M., SILverTown, J. AND TUCKER, C. 1990. Population ecology of heterostyle and homostyle Primula vulgaris: growth, survival and reproduction in field populations. $J$. Ecol., 78, 799-813.

BROWN, A. H. D. 1979. Enzyme polymorphism in plant populations. Theor. Pop. Biol., 15, 1-42.

BROWN, A. H. D. AND MARSHALl, D. R. 1981. Evolutionary changes accompanying colonization in plants. In: Scudder, G. G. E. and Reveal, J. L. (eds) Evolution Today, Carnegie-Mellon University, Pittsburgh, pp. 351-363.

CAHAlan, C. M. 1983. Neighbourhood size and population structure in Primula vulgaris Huds. Ph.D. Thesis, University of Wales.

CAHALAN, C. M. AND GLIDDON, C. 1985. Genetic neighbourhood sizes in Primula vulgaris. Heredity, 54 65-70.

CAVAlli-SForzA, L. L. AND EDWARdS, A. W. F. 1967. Phylogenetic analysis: models and estimation procedures. Evolution, 21, 550-570.

ELLSTRAND, N. M. 1992. Gene flow by pollen: implications for plant conservation genetics. Oikos, 63, 77-86.

EPPERSON, B. K. 1990. Spatial patterns of genetic variation in plant populations. In: Brown, A. H. D., Clegg, M. T., Kahler, A. L. and Weir, B. S. (eds) Plant Population Genetics, Breeding and Genetic Resources. Sinauer Associates Inc., Massachusetts, pp. 229-253.

FERGUSON, A. 1980. Biochemical Systematics and Evolution. Blackie, Glasgow \& London.

GOVINDARAJU, D. R. 1988. Relationship between dispersal ability and levels of gene flow in plants. Oikos, 52, 31-35.

GRIME, J. P., hOdgson, J. G. AND HUNT, R. 1988. Comparative Plant Ecology. Unwin Hyman, London.

HAMRICK, J. L. AND GODT, M. J. 1990. Allozyme diversity in plant species. In: Brown, A. H. D., Clegg, M. T., Kahler, A. L. and Weir, B. S. (eds) Plant Population Genetics, Breeding and Genetic Resources, Sinauer Associates Inc., Massachusetts, pp. 43-63.

HAMRICK, J. L., LINHART, Y. B. AND MITTON, J. B. 1979. Relationships between life history characteristics and electrophoretically-detectable genetic variation in plants. Ann. Rev. Ecol. Syst., 10, 173-200. 
LACK, A. J. 1982. The ecology of flowers of chalk grassland and their insect pollinators. J. Ecol., 70, 773-790.

LACK, A. J. AND KAY, Q. O. N. 1988. Allele frequencies, genetic relationships and heterozygosity in Polygala vulgaris populations in contrasting habitats in Southern Britain. Biol. J. Linn. Soc., 34, 119-147.

LEES, D. R. 1971. Frequency of pin and thrum plants in a wild population of the cowslip, Primula veris L. Watsonia, 8, 289-291.

LEVIN, D. A. AND KERSTER, H. W. 1974. Gene flow in seed plants. Evol. Biol., 7, 139-220.

LOVELESS, M. D. AND HAMRICK, J. L. 1984. Ecological determinants of genetic structure in plant populations. Ann. Rev. Ecol. Syst., 15, 65-95.

NEI, M. 1972. Genetic distance between populations. Am. Nat., 106, 283-292.

NEl, M. 1973. Analysis of gene diversity in subdivided populations. Proc. Natl. Acad. Sci., 70, 3321-3323.

NEI, M., MARUYAMA, T. AND CHAKRABORTY, R. 1975. The bottleneck effect and genetic variability in populations. Evolution, 29, 1-10.

PROCTOR, M. AND YeO, P. 1973. The Pollination of Flowers. Collins, London.

RICHARDS, A. J. AND IBRAHIM, H. 1978. Estimation of neighbourhood size in two populations of Primula veris. In: Richards, A. J. (ed.) The Pollination of Flowers by Insects, Academic Press, London, pp. 165-174.
ROGERS, J. S. 1972. Measures of genetic similarity and distance. Studies in Genetics, University of Texas Publications, 7213, 145-153.

SHAW, C. R. AND PRASAD, R. 1970. Starch gel electrophoresis of enzymes - a compilation of recipes. Biochem. Genet., $\mathbf{4}$, 297-320.

SIRKKomaA, s. 1983. Calculations on the decrease of genetic variation due to the founder effect. Hereditas, 99, 11-20.

SLATKIN, M. AND BARTON, N. M. 1989. A comparison of three indirect methods of estimating gene flow. Evolution, 41, 1349-1368.

SWOFFORD, D. L. AND SElander, R. B. 1989. Biosys-1. A computer program for the analysis of allelic variation in population genetics and biochemical systematics, release 1.7 . University of Illinois, Urbana, Illinois.

TAMм, C. o. 1972. Survival and flowering of some perennial herbs III. The behaviour of Primula veris on permanent plots. Oikos, 23, 159-166.

WEDDERBURN, F. AND RICHARDS, A. J. 1990. Variation in within morph incompatibility sites in heteromorphic Primula L. New Phytol., 116, 149-162.

WRight, s. 1951. The genetic structure of populations. Ann. Eugen., 15, 323-354. 